UNIVERSITY

OF DEBRECEN

FACULTY OF

Health

NYÍREGYHÁZA

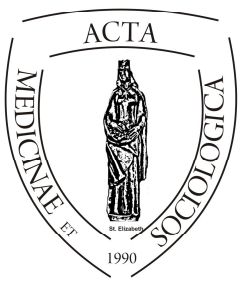

ACTA

MedSoc

VOLUME 6.

2015

\title{
A rendelkezésre álló kihasználatlan erőforrások - az endogén növekedéselmélet ${ }^{1}$
}

\author{
Jóna György
}

Debreceni Egyetem Egészségügyi Kar

\begin{abstract}
This paper deals with demonstrating the theoretical stages of regional economic growth, embracing Keynesian, exogenous and endogenous (it can be called as new development theory too) regional development theories. Moreover, presenting the normative theories, the positive aspects are emphasized such as triple helix policy and place based development policy as well. On the one hand, the paper is concerned with theories of local development; on the other it also shows empirical results meaning the surveys of concept of territorial capital. The empirical conclusions stress the Hungarian micro-regional development has been determined significantly by the relational and cultural capital namely endogenous assets have had crucial role in the economic growth.
\end{abstract}

Keywords: Endogenous growth, place-based policy, territorial capital, Hungarian microregions,

1 A kutatás a TÁMOP-4.2.4.A/2-11/1-2012-0001azonosító számú Nemzeti Kiválóság Program - Hazai hallgatói, illetve kutatói személyi támogatást biztosító rendszer kidolgozása és müködtetése konvergencia program címü kiemelt projekt keretében zajlott. A projekt az Európai Unió támogatásával, az Európai Szociális Alap társfinanszírozásával valósul meg. 


\begin{abstract}
Absztrakt: Ez a tanulmány a regionális gazdasági növekedés elméleti periódusait mutatja be, melyben megtalálható a Keynes-i, exogén és endogén (ezt gyakran új növekedéselméletnek is nevezzük) növekedéselmélet is. A normatív teóriák bemutatása után a pozitív aspektusokat hangsúlyozásuk úgymint a tripla csavar és a hely alapú gazdaságfejlesztési szakpolitikát. Ez a tanulmány egyrészről tehát a helyi növekedéselméletekkel foglalkozik, másrészt empirikus eredményeket is közöl, melyek területitőke-koncepción alapuló kutatásokból származnak. Az összefoglaló rész kiemeli, hogy a vizsgált időszakban a magyarországi kistérségi növekedést a kapcsolati és a kulturális tőke szignifikánsan meghatározta.
\end{abstract}

Kulcsszavak: endogén növekedés, hely alapú fejlesztéspolitika, területi tőke, magyar kistérségek

\title{
Bevezető
}

Ebben a tanulmányban elméleti általánosításokat, megállapításokat fogalmazok meg az endogén javak, valamint a regionális fejlődés és növekedés összefüggéseiről. Ugyanakkor az endogén, illetve új növekedéselmélet kialakulásának kronológiáját és legfontosabb jellemzőit is bemutatom ${ }^{2}$.

Az endogén javak a régióban található összes természetes erőforrást magukba foglalnak (humán töke, környezeti adottságok, tradíciók ápolása, a lakosok és vállalkozók közötti bizalom, stb.). Az úgynevezett új növekedéselmélet (amit szoktunk endogén növekedéselméletnek is nevezni) szerint a helyi társadalom jólétét, boldogságát az anyagi javak mellett egy sor gazdaságon kívüli tényező is (egészségi állapot, társadalmi egyenlőtlenségek mértéke, tiszta levegő, közbiztonság, stb.) meghatározza. Fejlődés nem csak akkor érhető el, ha újabb és újabb pénzügyi befektetések lesznek egy térségben, hanem akkor is, ha a meglévő természetes erőforrásait kihasználja a régió lakossága. Más aspektusból, a szociális állapotok a legszegényebb térségekben nem akkor fognak javulni, ha még több erőforrást allokálunk oda, hanem akkor, ha a helyi társadalom tagjai saját természetes erőforrásaikat felismerik és kihasználják. Ennek észlelése és gyakorlati alkalmazása a társadalompolitikában, a területfejlesztésben, a szociális munkában és e három terület integrálásában elengedhetetlen.

\footnotetext{
${ }^{2}$ A regionális növekedés és fejlődés kifejezések nem ugyanazt jelentik. A kettő között lényegi eltérés van, erről lásd részletesen Lengyel (2012) tanulmányát.
} 


\section{A regionális növekedés forrásai}

A regionális gazdaságtan egyik központi kérdése, hogy mely tényezők milyen mértékben határozzák meg, fokozzák a gazdasági növekedést és fejlődést. Mielött ennek részletes elemzésére kitérnék, néhány alkalmazott fogalmat definiálni kell. A regionális növekedés, bővülés, haladás kvantifikálható, számszerüsíthető kategóriaként értelmezhető, mely a régió gazdasági teljesítményének mennyiségi alakulásával, rendszerint a reál GDP-vel (GNP, GNI) áll kapcsolatban (Capello és Nijkamp, 2009). A gazdasági növekedés determinánsait Samuelson és Nordhaus (2005 716.p.) csoportosította, ezek a következők: népesség, technológiai fejlődés, tőkeállomány és természeti adottságok.

A regionális fejlődés kategóriája nem kvantitatív, inkább kvalitatív jellegü, mely a gazdasági determinánsok mellett egyéb szociokulturális háttérfeltételek változásait, hatásait is figyelembe veszi (Enyedi, 2010). Ez a megközelítés közel áll a területitőke-koncepcióhoz, mely az immateriális tőkefajtákat is figyelembe veszi. „A regionális fejlődésénél a térszerkezet és településhálózat, az intézményrendszer és kiépültsége, a környezet állapota, a régió önállósága, a közösség elvárásai, a lakosság egészségi állapota stb. is fontos mérlegelési szempont." (Lengyel, 2010 29.p.) Hasonló felfogáson van Lackó is, aki szerint: ,a területi fejlődés tartalmilag felöleli egy ország egészére, különböző részeire, a településre jellemző változásokat, a természeti erőforrások, a népesség, a termelés, az infrastrukturális hálózatok és ellátóintézmények területi eloszlási és változási viszonyait, a köztük meglévő kapcsolatokat.” (Lackó, 2009 27.p.). A két fogalom természetesen egymástól elválaszthatatlan, tartalmilag, logikailag összekapcsolódik, ám a precíz elemzés érdekében érdemes ezeket külön választani. A továbbiakban én is ezt teszem.

A különböző időszakokban egymástól jelentősen eltérő irányzatok domináltak a regionális gazdasági növekedés és fejlődés megítélésében. Azért változtak, illetve változnak ezek folyamatosan, mert a gazdasági, társadalmi, kulturális és politikai környezet is dinamikusan alakul, így a korábbi felfogások gyakorlati alkalmazásával nem lehetett megőrizni a regionális növekedés ütemét (Mulder, Nijkamp és Stough, 2012). Hangsúlyozni szeretném, nem arról van szó, hogy egyik növekedéselmélet jó, a másik pedig elfogadhatatlan - véleményem szerint mindegyik modell alkalmazható. Eredményességük attól függ, hogy milyen korban, melyik társadalomban és térgazdasági struktúrában, környezetben alkalmazzák.

\section{A keynesi elméleten alapuló növekedéselmélet}

Az 1960-as és 1970-es években a keynesi gazdaságfilozófia befolyása volt a legerősebb a regionális növekedéselméletben. Ennek lényege, hogy a piaci au- 
tomatizmusok nem tökéletesek, csupán néhány esetben, időszakonként képesek egyensúlyi helyzetet teremteni (de akkor sem minden piaci szegmensben). A piaci mechanizmusok egyenlőtlenséget implikálnak és reprodukálnak általában a fejlettebb régiók javára, a területi differenciálódás nő (Fenyővári és Lukovics, 2008). Éppen ezért a központi kormányzatnak intervenciót kell alkalmaznia a piaci kudarcok korrigálása érdekében; a legtöbb esetben az állam, illetve valamelyik helyi kormányzati intézmény a föszereplö. Bár felismerték a kormányzati kudarcokat is, úgy vélték, hogy ennek káros hatása kisebb, mint a piaci kudarcoké. Regionális szinten a közösségi beavatkozások, föként a kormányzati beruházások és kiadások multiplikátorhatást eredményeznek, így javulnak a foglalkoztatási mutatók, a kereslet élénkül, a növekedés elkezdődik. A kormányzati beruházás során munkahelyek létesülnek, csökken a régió munkanélküliségi rátája, magasabb bevétel realizálódik a lakosságnál, a fogyasztás javul, ami újabb beruházást implikál. Ez egy cirkuláris, önfenntartó fejlődést is eredményezhet. A lemaradt térségek esetében még hatékonyabb a kormányzati intervenció, mert az állami támogatásokkal ezeket a régiókat fel lehet zárkóztatni, ami a területi diverzifikáció mérséklődését jelenti. A költségvetési források megfelelő redisztribúciójával és a javak allokációjával a területi egyenlőtlenségek kezelhetővé válnak.

Domar és Harrod növekedési modelljükben rávilágítanak (Domar, 1946), hogy a beruházás nyomán piaci bővülés érhető el. A szerzőpáros a beruházásnak két fajtáját különböztette meg: az autonóm és indukált beruházást, az elsőt exogén adottságként értelmezték. Meglátásuk szerint az autonóm beruházásnak három determinánsa emelhető ki:

- állami kiadások, melyek a régiókba direkt vagy indirekt beruházásként jutnak el,

- stratégiai, hosszú távú beruházás, melyek a távolabbi jövőben térülnek meg (pl.: humán tőkébe való befektetés), végül

- technológiai fejlődés, amit szintén exogén tényezőnek tartottak. Szerintük ez olyan adottság, mely mindenféle ráfordítás nélkül mindenkinek rendelkezésére áll, „mannaként hull alá”. Véleményem szerint téves a technológiai haladást egyszerüen exogén hatásként értelmezni. Egyet értek a Nobel-díjas, kissé nyersen fogalmazó Kenneth Arrow-val, aki szerint ,a technikai fejlödés ilyen kezelése alapvetően a tudatlanság bevallása." (Arrow, 1962 155.p.)

Az indukált beruházás a fogyasztási javak iránti kereslettől függ. Ha a kereslet nő, akkor emelkedik a fogyasztási javak termelése, ami újabb beruházásokat indukál. Ez a folyamat fordítva is helytálló. 
A keynesi perspektíva hangsúlyozza, hogy a kormányzati szerepvállalásnak, pontosabban beruházásnak komplementer hatása is lehet. Meghatározott beruházás esetén a lokális társadalom jövedelme nő, ami a fogyasztást serkenti, ami újabb piaci beruházásokat indíthat el. Hirschmann és Nelson (1976) szerzőpárosa komplementer hatásnak két fajtáját emeli ki:(1) az előrecsatoló (kínálatban nyilvánul meg) és a (2) visszacsatoló (kereslethez kapcsolódik) effektust. Előrecsatoló hatásról akkor beszélhetünk, ha a kormányzati beruházás során létrejött termelési egységek termékeihez kapcsolódik, vagy azt kiegészíti egy újabb termék, amit egy másik piaci szereplő biztosít, ezzel javul a régió foglalkoztatási szerkezete. A visszacsatoló hatás lényege az, hogy a termeléshez szükséges áruk létrehozásához társul újabb termelési egység. Végső soron, a központi beruházásnak tovagyürüző hatása van, mely hosszabb távon nem torzítja a piaci automatizmusokat, hanem serkenti.

\section{Az exogén növekedéselmélet}

Az 1973-as olajválság-sorozat kirobbanása után a regionális és nemzetközi társadalmi, gazdasági háttérfeltételek gyökeresen megváltoztak. A keynesi felfogás helyére a neoklasszikus exogén regionális növekedéselmélet kerül (Lukovics, 2008). Ez Solow-modelljét (Solow, 2000) veszi alapul, melyben a monetáris és racionális gondolkodás dominál. A kormányzati intervenció kritikája felerősödött, helyette a „,piac láthatatlan kezé”-ben bíztak, a piac hatékonyabb a források (újra)elosztásában, mint az állam: szerintük a kormányzati kudarcok károsabbak, mint a piaci kudarcok. A piaci kudarcokat állami intervencióval részlegesen, vagy nem is lehet korrigálni, a kormányzati beavatkozás káros, drága, ezért a piac önreflexióját hagyni kell kibontakozni, mely képes növekedési pályára állítani a régiót (Káposzta és Nagy, 2012). Elfogadottá vált az a nézet, miszerint a regionális gazdasági növekedést és fejlődést jobban serkentik a piaci automatizmusok, a régiók közötti verseny,mint a közösségi intervenciók. Mindezt meghatározza:

- a munkaerő-piaci kínálat szerkezete, fejlődése és bővülése,

- a technológiai fellendülés, valamint a

- tőkeállomány növekedése.

Ez az elmélet feltételezi, hogy a tőke- és a munkaerő szabad áramlása adott, a régiók közötti verseny tökéletesen szabad, a termelési tényezők mobilitását nem gátolja semmi, a jövedelem mértéke a termelés output-jától függ. Ebből következik, hogy a magasabb életszínvonalat biztosító régió vonzóvá válik, így megkezdődik az országon belüli migráció, a szegényebb térségekből vándorolnak a gazdagabbak felé. A szabadpiaci elvek térnyerése következtében a tőkemozgást sem korlátozza semmi. A tőke a gyorsabb megtérülést keresi, oda helyezik át, 
ahol alacsonyabb munkabért kell fizetni. A tőke és a munkaerő migrációja tehát ellentétessé válik, így a területi, gazdasági és társadalmi egyenlőtlenségeket a piaci önszabályozók - kisebb-nagyobb ingadozásokkal, de - megoldják. Közösségi intervencióra tehát nincs, vagy alig van szükség, az állam partvonalon kívülre kerül (Capello, 2007 756.p.). E megközelítés bírálata korán kialakult, a gyakorlat hamar felülírta ezeket a szcenáriókat. A valóságban, ezzel szemben, a tőke nem minden esetben vándorol át alacsonyabb jövedelmü régiókba a gazdagabbakból, mert ott általában alacsonyabb iskolai végzettséggel rendelkező munkaerő él, a technológiai eszközök sem túl fejlettek, a kibocsátás növekedésével összefüggő feltételek nem adottak; a regionális differenciálódásokat a piaci automatizmusok csupán részlegesen kezelik.

Álláspontom szerint a keynesi felfogás kritikája itt többé-kevésbé helytálló, valóban a kormányzat túl magas arányban von, illetve vonhat el forrásokat a gazdaság szereplőitől a központi beruházások érdekében. Több esetben az ilyen típusú beavatkozás nem eredményes, a piaci mechanizmusok a beruházásra szánt források allokációjában rendszerint hatékonyabbak. Egyetértek Milton Friedman megállapításával, hogy a kelet- és közép-európai államokban rendszerint előfordul, hogy a problémára adott kormányzati reakciók még nagyobb gondot okoznak, mint amekkora az eredeti probléma volt.

\section{Az endogén, illetve új növekedéselmélet}

A következö évtizedben a neoklasszikus endogén növekedéselmélet (Button, 2011) kiterjesztésének hatására a régiók endogén kapacitásaiban látták a gazdasági bővülés hajtóerejét (Ács és Varga, 2000). Ezt a változást az indokolta, hogy makrogazdasági szinten nem tudták megmagyarázni a konvergencia hiányát, illetve annak speciális formáit. Csupán néhány leszakadt régió volt képes a felzárkózásra, ám a neoklasszikus elmélet szerint többnek kellett volna bekapcsolódnia ebben a folyamatba (Margarian, 2013). „Az új növekedéselmélet képviselői szerint az empirikus kutatások nem támasztják alá a neoklasszikus modellek legfontosabb következtetéseit és feltételezéseit, nevezetesen a konvergenciahipotézist és a minden országot egyformán érintő technológiafejlődés létezésére vonatkozó feltevést." (Valentinyi, 1995 586.p.) Az exogén források helyett az endogén kapacitásokkal, forrásokkal és folyamatokkal hozták összefüggésbe, magyarázták a regionális gazdaság fejlődését. Ennek a megközelítésnek a lényege, hogy a térség endogén forrásait fel kell ismerni, mobilizálni kell és - amennyiben ennek relevanciája van - ezeket be kell emelni a termelési folyamatba. A régió belső kapacitásaira akkor irányult a figyelem, mikor először felismerték, hogy a lokális technológiának milyen erős befolyásoló hatása van a helyi növekedésre, majd a humán tőke szerepét vizsgálták (Stimson, Stough és Nijkamp, 2011 5.p.). Ezután a Romer (1990) és Lucas (1993) tanulmányain alapuló megközelítések fejlesztették az endogén 
növekedéselméletet, vagyis a humán erőforrások fejlesztésével az innováció bővülhet, ami újabb beruházásokkal a régió magasabb jövedelemképződését teszi lehetővé. Majd Fukuyama (1995) kezdett érdeklődni a nem-tárgyi tőkejavak területi hatása iránt, még pontosabban, a kulturális és társadalmi effektusokat elemezte. Kiemelt figyelmet kapott az, hogy a szilícium-völgyi, illetve közeli kis- és középvállalkozások(továbbiakban: KKV-k), egyetemek és üzleti körök, befektetök közötti bizalom, együttmüködés milyen hatással van a regionális folyamatokra.

$\mathrm{Az}$ endogén növekedéselméleti modell a regionális versennyel kapcsolatos felfogást részben módosította. Eszerint, nem a régiók közötti verseny, hanem sokkal inkább az endogén kapacitások kollektív együttmüködéssel történő kihasználása járul hozzá a regionális növekedéshez. Nem kell megszüntetni a lokális versenyt, ám a térségek közötti kooperációra a korábbihoz képest nagyobb hangsúlyt kell helyezni. A versenyelönyök helyett az együttmüködésre, kooperációra épülő előnyöket kell erősíteni.

E felfogás kiindulópontja az, hogy a térség belső adottságait, a már meglévő földrajzi, társadalmi, gazdasági, kulturális, tradicionális, stb. tényezőit kell felismerni és mozgósítani a regionális növekedés érdekében.

Valentinyi (1995) az endogén növekedés három forrását különbözteti meg, melyek egymáshoz szorosan kapcsolódnak: (1) a tudás, humán tőke, az (2) innováció, valamint a (3) régióban meglévő területi potenciálok. Lengyel (2010 4547.p.) az endogén növekedés 4 determinánsát emeli ki, úgymint humán tőke, technológiai fejlettség, innováció, tőkeintenzitás (tőke/munka aránya). Lukovics (2008) a régión belül az endogén forrásoknak több elemét emeli ki, úgymint:

- tőkemennyiség,

- földrajzi adottság,

- a régió munkaerejének minőségi és mennyiség összetétele,

- fizikai infrastruktúra minősége,

- társadalmi, kulturális, tradicionális háttér,

- hatalmi (központi- vagy önkormányzati) intézményrendszer döntései,

- piaci szereplök kapcsolatrendszere,

- környezeti állapot.

Az elgondolás az, hogy a humán tőke és a technológia fejlödés összekapcsolásával indítható el a regionális bővülés. A magas tudásalapú üzletágak (magas hozamú szektorok egységei) közelébe költöznek a magas tudásbázissal, piacképes ismeretekkel rendelkező társadalmi csoportok (Capello, 2012). Ebben a funkcionális térben a lexikális és tacit tudás koncentráltan megjelenik, amely ha bizonyos kritikus tömeget elér, akkor regionális növekedést indít el. A tudásból ered az innováció, melyhez szerves módon társulnak az endogén regionális növeke- 
dést meghatározó további faktorok, úgymint a vállalkozókészség, a területileg beágyazódott intézmények, a jó képességekkel és kapcsolatokkal rendelkező menedzsment és kreativitás (Chapain, Clifton, és Comunian, 2013). Ezek az endogén források egymáshoz rendelve a régió termelékenységét, a lakosság életszínvonalát javítják.

A regionális egyenlőtlenségeket a tudás differenciált területi megoszlásával magyarázza a teória. A kiegyenlítődés akkor valósul meg, ha a fejlettebb régiókból a tudás „túlcsordul” (spillover) a feltörekvő területekre, ott elér egy kritikus tömeget és a növekedés forrásává válik. A tudás túlcsordulása azonban nem akadálymentes. Az alulfejlett régiókban nem, vagy csak elhanyagolható mértékben van meg az új tudás (new knowledge) iránti nyitottság, önmagukat zárják ki a növekedés folyamatából. A diffúzió (új tudás által termelt áru terjedése) részlegesen valósul meg. Ennek hátterében társadalmi, kulturális, esetleg szociálpszichológiai magyarázatok is állnak.

Szeretném azt hangsúlyozni, hogy nem minden tudás alkalmas a regionális növekedés elinditására, meghatározó a tudás minösége és piacképessége. A piaci kereslethez, illetve a beruházáshoz hozzá kell igazitani a lokális társadalom tudását, csak ekkor lehet a humán eröforrást pénztökévé transzformálni. Adott régióban a diplomások arányának növekedése ezért nem minden esetben vezet növekedéshez.

A területitőke-modell fejlesztéspolitikája szintén az endogén növekedéselméletből bontakozott ki. Ennek lényege, hogy a professzionális és strukturális részeket érintő fejlesztéspolitikát felváltotta a stratégiai tervezéssel összefüggésben álló gondolat. Ez olyan kínálatorientált szemléletet foglal magába, mely a meglévő materiális és immateriális javak kihasználásával indítja el a regionális növekedést. A területitőke-modell fejlesztési koncepcióinak betartásával - szigorúan elméletileg - a területi növekedés elindul, illetve a területitőke-állomány nő. Ahogy azt az 1. ábra is mutatja, a fejlesztéspolitikai térben a növekedés dinamikus, majd eléri maximális értékét, amit a területi hatékonyság határoz meg. Ezután inkább a fenntartható fejlődés tényezőit kell felismerni és hasznosítani. 


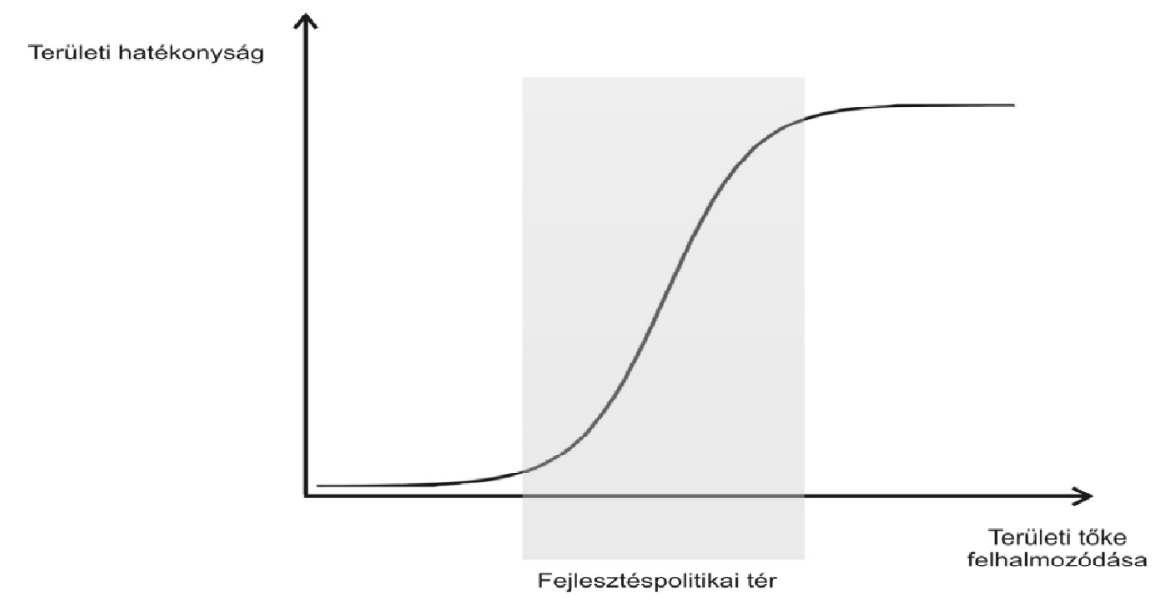

Forrás: Camagni-Capello 2005 7.p.

1. ábra: A területitőke-koncepció fejlesztéspolitikájának hatása.

Az endogén növekedéselmélet fejlesztéspolitikája a fejlesztések fenntarthatóságával áll szoros kapcsolatban. Ennek lényege az úgynevezett „hármas spirálcsavar szcenárió"-val (triple helix scenario) interpretálható (Etzkowitz és Leydesdorff, 2000), mely az ipar, az egyetem és kutatóintézet, valamint az önkormányzat közötti spirális összefonódásra, kooperációra mutat rá. Ebben a konstellációban az oktatói és kutatói szektor szerepe jelentős, ahol a tudás alapú gazdaság tényezői koncentrálódnak. Florida (2002) szerint ez a szinergia a lokális társadalmi viszonyrendszereket is átrendezi, ilyen területeken alakul ki a kreatív társadalmi osztály, mely ágazati körzetet, funkcionális teret alkot, ez tudásával, mindennapi munkájával és életével a térség innovációs miliőjét is megteremti, ezzel újból serkenti a regionális növekedést (Gabe, Florida és Mellander, 2013).

A fenntartható fejlődést öt kritikus sikerességi faktor pentagon modellje integrálja (Capello, Nijkamp és Pepping, 1999; Nijkamp, Vleugel és Maggi, et.al. 1994) az endogén növekedéselméletbe. Ezeket a tényezőket tőkeként fogják fel az elmélet alkotói. Kiemelik, hogy a regionális bővülés folyamatában az alábbi öt tőkefajtának mobilizálhatóvá kell válnia, a köztük lévő transzformációt meg kell örizni:

1. termelési tőke: itt a termeléssel és a munkával összefüggésben álló tényezők szerepelnek, 
2. humán tőke: ide azok a tudás- és képességformáló képzések, tréningek tartoznak, melyek a munkaerő minőségét javítják, végső soron a termelési output minőségi és mennyiségi fenntartását határozzák meg,

3. társadalmi tőke: ez olyan gyüjtőfogalom, mely magába foglalja a rászoruló társadalmi csoportok szociális támogatását, az egyének közötti kommunikációját, a formális és informális üzleti hálózatok interakcióit, valamint a társadalmi és gazdasági határokon átívelő kommunikációs csatornákat,

4. kreatív tőke: olyan képességek és készségek kapcsolódnak ide, melyek alkalmasak egy egész régió gazdaságát növekedési pályára állítani. Mindezt meghatározza a vállalkozókészség, a termeléssel összefüggő új gondolatok adaptálása. Ezek a feltételek leggyakrabban a városi multikulturális ,olvasztótégely”-ekben adottak (Stimson, Stough és Nijkamp, 2011 11.p.),

5. ökológiai töke: a környezeti tényezők az életminőséget befolyásolják hosszú távon, ezért a zöldterületek, a víz, stb. minőségi és mennyiségi fenntartására irányuló stratégiák a régió jólétét jelzi.

A fenti pentagonszerü struktúrába rendezett endogén növekedés fenntarthatóságával kapcsolatos tényezők empirikus tesztelését, mérését, kvantifikációját és magyarázó modelljét már kidolgozták (Capello, Nijkamp és Pepping, 1999).

\begin{tabular}{|c|c|c|c|c|c|}
\hline $\begin{array}{c}\text { Elméleti } \\
\text { szem- } \\
\text { pontok }\end{array}$ & $\begin{array}{l}\text { Keynes-i } \\
\text { irányzat }\end{array}$ & $\begin{array}{c}\text { Neoklasszikus } \\
\text { (exogén) } \\
\text { irányzat }\end{array}$ & $\begin{array}{c}\text { Neoklasszikus } \\
\text { (endogén) } \\
\text { irányzat }\end{array}$ & $\begin{array}{c}\text { Neoklasszi- } \\
\text { kus } \\
\text { (heterodox) } \\
\text { irányzat }\end{array}$ & $\begin{array}{l}\text { Területi } \\
\text { irányzat }\end{array}$ \\
\hline Időszak & $\begin{array}{l}\text { 1960-70-es } \\
\text { évek }\end{array}$ & 1960-70-as évek & 1980-90-es évek & $\begin{array}{l}\text { 1980-90-es } \\
\text { évek }\end{array}$ & $\begin{array}{l}\text { 1990-2000-es } \\
\text { évek }\end{array}$ \\
\hline $\begin{array}{l}\text { Gazdasági } \\
\text { növekedés } \\
\text { értelmezé- } \\
\text { se }\end{array}$ & $\begin{array}{l}\text { Jövedelmek és } \\
\text { foglalkoztatás } \\
\text { növekedése }\end{array}$ & $\begin{array}{l}\text { Termelékenység } \\
\text { és az életszín- } \\
\text { vonal javulása }\end{array}$ & $\begin{array}{l}\text { Termelékenység } \\
\text { és az életszínvo- } \\
\text { nal javulása }\end{array}$ & $\begin{array}{l}\text { Verseny- } \\
\text { képesség } \\
\text { javulása }\end{array}$ & $\begin{array}{l}\text { Versenyképesség } \\
\text { javulása }\end{array}$ \\
\hline $\begin{array}{l}\text { Növeke- } \\
\text { dési ténye- } \\
\text { zők }\end{array}$ & Kereslet & $\begin{array}{l}\text { Tényező- } \\
\text { ellátottság és } \\
\text { termelékenység }\end{array}$ & $\begin{array}{l}\text { Termelékenység } \\
\text { növekedésének } \\
\text { endogén forrásai }\end{array}$ & $\begin{array}{l}\text { Nem- } \\
\text { hagyományos } \\
\text { tényező- } \\
\text { ellátottság } \\
\text { javulása }\end{array}$ & $\begin{array}{l}\text { Endogén terület } \\
\text { elemek }\end{array}$ \\
\hline $\begin{array}{l}\text { Elméleti } \\
\text { alapok }\end{array}$ & $\begin{array}{l}\text { Exportbázis- } \\
\text { elmélet, kumu- } \\
\text { latív okság } \\
\text { elmélet }\end{array}$ & $\begin{array}{l}\text { Régiók közötti } \\
\text { tényezőáramlás }\end{array}$ & $\begin{array}{l}\text { Makroökonómiai } \\
\text { endogén növeke- } \\
\text { dés-elméletek }\end{array}$ & $\begin{array}{l}\text { Növekedési } \\
\text { potenciál- } \\
\text { elméletek }\end{array}$ & $\begin{array}{l}\text { Kistérségi en- } \\
\text { dogén növeke- } \\
\text { dési elméletek }\end{array}$ \\
\hline
\end{tabular}

Forrás: Capello 2007 757.p.

1. táblázat: A regionális gazdasági növekedési elméletek főbb közgazdaságtani irányzatai. 
Eddigi területi kutatásaim éppen az endogén növekedéselmét lényegét támasztják alá (Jóna 2013, Jóna és Hajnal 2014). Ha csak az exogén tőkejavak kistérségi megoszlását vizsgájuk, kiderül, hogy a területi egyenlőtlenségek drasztikusak, az ország „nyugatról keletre lejt”. Azonban, ha az exogén és endogén kapacitásokat egyszerre vesszük figyelembe, akkor a kép jelentősen átalakul (az exogén és endogén javakat egyszerre a területi tőke kategóriával lehet mérni). A 2. ábrán is látható, hogy a legnagyobb területi tőke növekedés az ország legszegényebb kistérségeiben volt mérhetö.

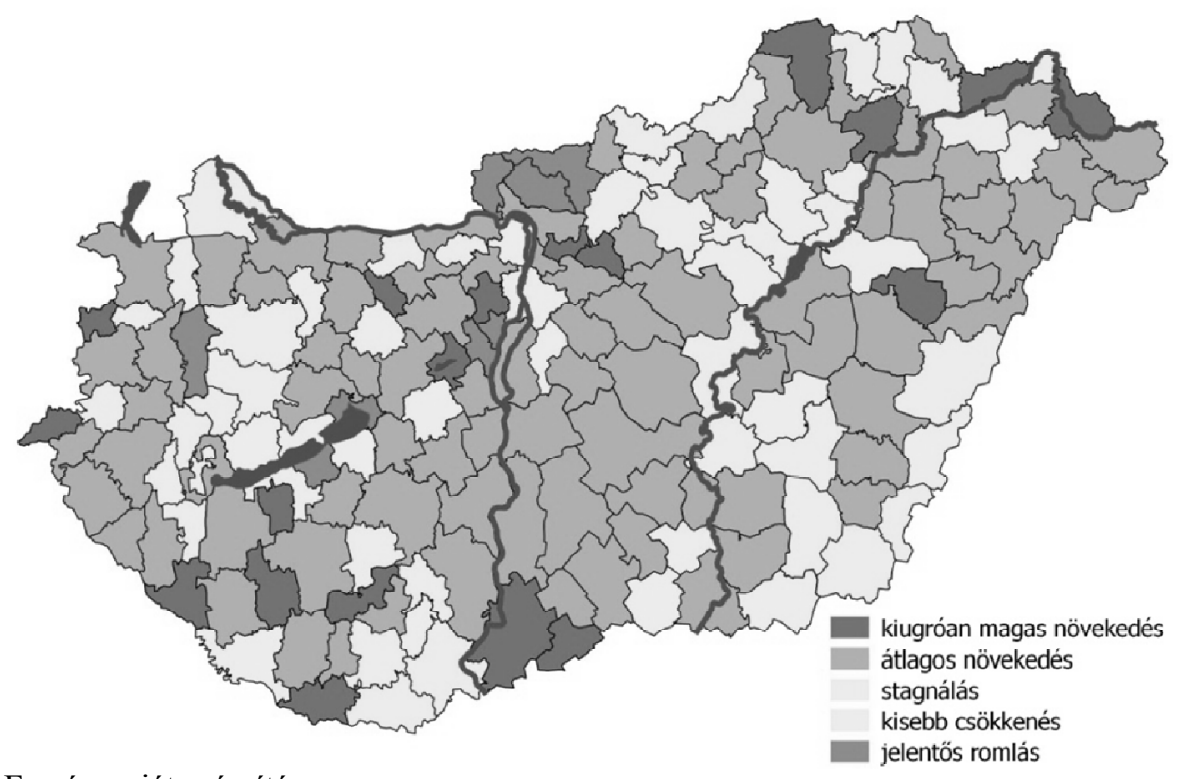

Forrás: saját számítás

2. ábra -A 2004 és 2010 közötti területitőke-értékek változása kistérségenként.

Ez egyértelmüen azt jelenti, hogy a periférikus kistérségeknek megvan az adottságuk, lehetőségük a felzárkózásra, a konvergenciára. Ezek a területi endogén források azonban nincsenek kihasználva, így a szocioökonómiai különbségek megmaradnak. Az egyenlötlenségek mérséklődnének, ha az endogén kapacitások felismerése és aktivizálása megtörténne. A kérdés tehát az, miként lehet az endogén kapacitásokat anyagi javakká transzformálni?

Jelenleg ez a kérdés foglalkoztatja a legnevesebb nemzetközi kutatóintézeteket is. Az eredmények nyilvánvalóan régiónként eltérőek, ám néhány általánosítás mégis megfogalmazható. A leszakadt régiók akkor tudják saját, már 
meglévő erőforrásaikat mobilizálni, ha kooperálnak egymással, tudásukat, tradícióikat, képességeiket a termelési folyamatba állítják. Röviden, a helyi civil társadalom, a gazdasági szereplők, az önkéntesek és az egyetemek és kutatómühelyek közösen, egymással kooperálva, hálózatokat alkotva képesek aktivizálni. A területfejlesztési és a társadalompolitikai eszközöket integrálják, a kettő egymástól elválaszthatatlan.

Ezt a kutatási eredményt ma már beépítették az angol (Hildreth, 2014, Pugalis, 2014), a lengyel (Dabrowski, 2014), az ausztrál (Mcdonald, 2014) és az olasz (Celata és Coletti, 2014) fejlesztéspolitikába is. Ezekben az államokban a szubszidiaritás elvét követve többszintủ kormányzást valósítanak meg, ahol az államnak már nincs főszerepe, mert felismerték ennek határait, lehetőségeit. Jellemző, hogy hálózatok, network-ök alakulnak helyileg, melybe beletartoznak a régió üzletemberei, a civil szervezetek képviselöi, KKV-k, és a tudomány képviselői is. Ők készítik el közösen a térség rövid-, közép- és hosszú távú fejlesztési stratégiáját és ők is valósítják meg.

\section{Összefoglalás}

Röviden összefoglalva az eddigieket, elmondható, hogy a regionális növekedéssel kapcsolatos elméletek az utóbbi fél évszázadban jelentős átalakuláson mentek keresztül. Az 1960-70-es években úgy vélték, hogy a területi növekedés forrásai közé sorolható a közlekedési infrastruktúra, az agglomerációs előnyök, a tradicionális tényezőellátottság, az ipari- és pénzügyi szektor múködése. A területitőke-paradigma által is elfogadott modern megközelítés szerint újabb faktorok is szerepet játszanak a regionális növekedésben, úgymint a területi identitás és fogékonyság, a tudás termelés és diffúzió, a területi miliő és szinergiák, valamint a kollektív tanulás folyamata.

\section{Felhasznált irodalom}

1. Ács J. Z., Varga A. (2000): Térbeliség, endogén növekedés és innováció. Tér és Társadalom, 4 23-39.p.

2. Arrow, K. J. (1962): The economic implication of learning by doing. The Review of Economic Studies, 3 (29) 155-173.p.

3. Button, K. (2011): The economist's perspective on regional endogenous development. 20-39. p. In.: Stimson, R., Stough, R. R., Nijkamp, P. (eds.): 
Endogenous regional development: perspectives, measurement and empirical investigation. Massachusetts: Elgar.

4. Camagni, R. (2011): Local knowledge, national vision. 57-65.p. In.: Seminar on territorial dimension of development policies. http://www.mrr.gov.pl/english/Regional_Development/Presidency/event_sh edule/Documents/Seminar_\%20Papers_and_Proceedings.pdf\#page $=59$ (letöltés: 2013. március 21.)

5. Camagni, R., Capello, R. (2005): Spatial scenarios and orientations in relation to the ESDP and EU cohension policy.http://www.espon.eu/ export/sites/default/Documents/Projects/ESPON2006Projects/CoordinatingCros sThematicProjects/Scenarios/2.ir_3.2-full.pdf (letöltve: 2012. augusztus 2.)

6. Capello, R. (2007): A forecasting territorial model of regional growth: the MASST model. The Annals of Regional Science, 4 753-787.p.

7. Capello, R. (2012): The knowledge economy in European regions: a strategic goal for competitiveness. 77-107.p. In.: Capello, R., Dentinho, T. P. (eds.): Networks, space and competitiveness. Massachusetts: Edwar Elgar.

8. Capello, R., Nijkamp, P. (2009) (eds.): Handbook of regional growth and development theories. Edward Elgar: Cheltenham, 535.p.

9. Capello, R., Nijkamp, P., Pepping, G. (1999): Sustainable cities and energy policies. Berlin: Springer-Verlag.

10. Celata, F. - Coletti, R. (2014): Place-based strategies or territorial cooperation? Local Economy, (megjelenés alatt).

11. Chapain, C., Clifton, N., Comunian, R. (2013): Understanding creative regions. Regional Studies, 2 (47) 131-134.p.

12. Dabrowski, M. (2014): Towards place-based regional and local development strategies in Central Eastern Europe? Local Economy, (megjelenés alatt).

13. Domar, E. (1946): Capital expansion, rate of growth, and employment. Econometria, 2 (14) 137-147.p.

14. Enyedi GY. (2010): A terület- és településfejlesztéssel kapcsolatos tudományos kutatások fó irányai és feladatai. Területi Statisztika, 4 (50) 398-405.p.

15. Etzkowitz, H., Leydesdorff, L. (2000): The dinamics of innovation. Research Policy, 2 (29) 109-129.p.

16. Fenyővári ZS., Lukovics M. (2008): A regionális versenyképesség és a területi különbségek kölcsönhatásai. Tér és Társadalom, 2 1-20.p.

17. Florida, R. (2002): The rise of the creative class: and how it's transforming work, leisure, community and everyday life. New York: Basic Book.

18. Fukuyama, F. (1995): Trust: The social virtues and creation of prosperity. New York: Free Press. 
19. Gabe, T., Florida, R., Mellander, C. (2013): The creative class and the crisis. Cambridge Journal of Regions, Economy and Society, 6: 37-53.p.

20. Hildreth, P. (2014): Place-based economic strategy in England. Local Economy, (megjelenés alatt).

21. Hirschmann, A., Nelson, R. R. (1976): Discussion. American Economic Review, 2 (66) 386-391.p.

22. Jóna Gy. (2013): A területi tőke fogalmi megközelítései. Tér és Társadalom, (27) 1: 30-51.p.

23. Jóna Gy., Hajnal B. (2014): A magyarországi kistérségek területi tőkéjének alakulása. Területi Statisztika, (54) 2: 99-118.p.

24. Káposzta J., Nagy H., Kollár K. (2010): Borsod-Abaúj-Zemplén és Szabolcs-Szatmár-Bereg megye leghátrányosabb helyzetü kistérségeinek települési szerkezeti, foglalkoztatási jellemzői az EU csatlakozás óta eltelt időszakban. Területi Statisztika, 6 (13) 641-658.p.

25. Lackó L. (2009): A területi fejlődés egységes értelmezése. 27-38.p. In.: Rechnitzer J. - Lengyel I. (szerk.): A regionális tudomány két évtizede Magyarországon. Budapest: Akadémiai Kiadó 468.p.

26. Lengyel I. (2010): Regionális gazdaságfejlesztés. Versenyképesség, klaszterek és alulról szerveződő stratégiák. Budapest: Akadémiai Kiadó, 386.p.

27. Lucas, R. E. (1993): Making a miracle. Economtria, 2 (61) 251-272.p.

28. Lukovics M. (2008): Térségek versenyképességének mérése. Szeged: JATEPress, 212.p.

29. Margarian, A. (2013): A constructive critique of the endogenous development approach in the European support of rural areas. Growth and Change, 1 (44) 1-29.p.

30. McDonald, C. (2014): Developing information to support the implementation of place-based economic development strategy. Local Economy, (megjelenés alatt).

31. Mulder, P., Nijkamp, P., Stough, R. (2012): Editorial. Spatial Economic Analysis, 3 (7) 287-291.p.

32. Nemes Nagy J. (2009): Terek, helyek, régiók. A regionális tudomány alapjai. Budapest: Akadémai Kiadó.

33. Pugalis, L. (2014): Trend sin place-based economic strategy. Local Economy, (megjelenés alatt).

34. Romer, P. M. (1990): Endogenous technical change. Journal of Political Economy, (98) 1002-1037.p.

35. Samuelson, P. A., Nordhaus, W. D. (2005): Közgazdaságtan. Budapest: Közgazdasági és Jogi Kiadó. 763.p.

36. Solow, R. M. (2000): Growth theory: an exposition. New York: Oxford University Press. 
37. Stimson, R., Stough, R., Nijkamp, P. (2011): Endogenous regional development. 1-20.p. . In.: Stimson, R., Stough, R. R., Nijkamp, P. (eds.): Endogenous regional development: perspectives, measurement and empirical investigation. Massachusetts: Elgar.

38. Valentinyi Á. (1995): Endogén növekedéselmélet. Közgazdasági Szemle, 6 582-594.p.

39. Polko, A.: Public space development in the context of urban and regional resilience, Journal of Economics and Management, 10: 48-58.

40. Baron M., Ochojski A., Polko A. et al.: Economics and Strategic Management of Local Public Services in Central Europe, Academy of Sciences of the Czech Republic, Prague. 2014.

Dr. Jóna György a Debreceni Egyetem Egészségügyi Karának adjunktusa, 2013-ban szerezte meg regionális gazdaságtanból Ph.D. fokozatát a Szent István Egyetemen. Kutatási területe a helyi gazdasági fejlődés tényezőinek elemzése, még pontosabban a KKV-hálózatok területi dimenzióinak feltérképezése. 